$\underline{\text { Araștırma Makalesi }}$

\title{
Karpuz Genetik Kaynaklarında Ovül-Ovaryum Kültürü Yöntemiyle Haploid Bitki Elde Edilmesi"
}

$\ddot{O} \mathbf{z}$

\author{
Çağlar YILDIZ1， İlknur SOLMAZ ${ }^{1,2 *}$
}

Ginogenezis, döllenmemiş ovaryum, ovül veya dişi gametofitlerin kültüre alınması işlemidir. Bu çalışma, karpuz genetik kaynaklarında ovül-ovaryum kültürü yöntemiyle haploid bitki elde etmek amacıyla yapılmıştır. Çalışmada 4 genotip; Kar 23, Kar 37, Kar 116 ve Kar 147 kullanılmıştır. Besi ortamina farklı dozlarda 2,4-D (2.5 mg/l-5 mg/l) ve TDZ (0.5 mg/l-1 mg/l) hormonlar1 ve poliaminlerin (putresin ve spermidin) $500 \mu \mathrm{M} / 1$ dozu ayrı ayrı ve her ikisi birlikte eklenmiştir. Toplam 16 farklı ortam kombinasyonu kullanılmış ve her bir ortama MS +8 g/l agar +30 g/l sakkaroz ilave edilmiştir. Çalışmada iki farklı deneme kurulmuştur. Birinci denemede, dişi çiçekler antezisten 1 gün önce toplanmış, ovaryumlar ve izole edilen ovüller kültüre alındıktan sonra karanlıkta $35^{\circ} \mathrm{C}$ 'de 3 gün sıcaklık şoku ön uygulaması yapılmış, ardından iklim odalarına (30004000 lüks 1şık yoğunluğuna sahip) yerleştirilmiştir. İkinci denemede, dişi çiçekler antezisten 2 gün önce toplanmış, ovaryum ve izole edilen ovüller kültüre alındıktan sonra iklimlendirme odalarına transfer edilmiştir. Elde edilen sonuçlara göre; genotipler arasında farklı seviyelerde ovül-ovaryum gelişimi ve kallus oluşumu görülmekle birlikte embriyo oluşumu ve bitkicik gelişimi Kar 37 ve Kar 147 genotiplerinde, $2.5 \mathrm{mg} / 1$ 2,4-D + $1 \mathrm{mg} / 1 \mathrm{TDZ}+500 \mu \mathrm{M} \mathrm{SPD}, 2.5 \mathrm{mg} / 1$ 2,4-D + $1 \mathrm{mg} / 1 \mathrm{TDZ}+$ $500 \mu \mathrm{M}$ PUT ve $5 \mathrm{mg} / 1$ 2,4-D + $0.5 \mathrm{mg} / \mathrm{l} \mathrm{TDZ}$ bulunan ortamlarda gözlendiği saptanmış, ancak bunlardan tam bir bitki elde edilememiştir.

Anahtar Kelimeler: Karpuz (Citrullus lanatus L.), genetik kaynak, haploid, spermidin, putresin

\section{Obtention of Haploid Plant in Watermelon Genetic Resources by Ovul-Ovary Culture Method}

\begin{abstract}
This study aimed to obtain haploid plant with the method of ovule-ovary culture using genetic resources of watermelon. In this study, four genotypes Kar 23, Kar 37, Kar 116 and Kar 147 were used. Different doses of 2,4-D (2.5 mg/l-5 mg/l) and TDZ (0.5 mg/l-1 mg/l) hormones and polyamines $(500 \mu \mathrm{M} / 1$ of putrescine and spermidine) were added into medium separately and together. Totally 16 different media combinations supplemented with $8 \mathrm{~g} / \mathrm{l}$ agar and $30 \mathrm{~g} / \mathrm{l}$ sucrose were used. Two different experiments were established in this study. In the first experiments, female flowers were collected 1 day before anthesis ovaries and excised ovules were cultured after heat shock pre-treatment at $35^{\circ} \mathrm{C}$ in dark for 3 days and then they were placed in climate controlled chambers (having 3000-4000 lux light density). In the second experiments, female flowers were collected 2 days before anthesis, ovaries and excised ovules were cultured after and then transferred into climate controlled chambers. According to obtained results, different level of ovule-ovary development and the cülus formation were observed at different ratem among genotypes. Embryo and plantlet developments were observed in the media which contain $2.5 \mathrm{mg} / 1$ 2,4-D + $1 \mathrm{mg} / \mathrm{l} \mathrm{TDZ}$ $+500 \mu \mathrm{M}$ SPD, $2.5 \mathrm{mg} / 1$ 2,4-D + $1 \mathrm{mg} / \mathrm{l} \mathrm{TDZ}+500 \mu \mathrm{M}$ PUT and $5 \mathrm{mg} / 1$ 2,4-D + $0.5 \mathrm{mg} / \mathrm{l} \mathrm{TDZ}$ for genotypes of Kar 37 and Kar 147 but full plant development from these plantlets have not been obtained.
\end{abstract}

Keywords: Watermelon (Citrullus lanatus L.), genetic resources, haploid, spermidine, putrescine

ORCID ID (Yazar sırasına göre)

0000-0002-2499-5925, 0000-0003-2996-0286

Yayın Kuruluna Geliş Tarihi: 20.06.2020

Kabul Tarihi: 25.06.2020

${ }^{1}$ Çukurova Üniversitesi, Fen Bilimleri Enstitüsü, Biyoteknoloji Anabilim Dalı, Adana, Türkiye

${ }^{2}$ Çukurova Üniversitesi, Ziraat Fakültesi, Bahçe Bitkileri Bölümü, Adana, Türkiye

*E-posta: isolmaz @ cu.edu.tr 


\section{Karpuz Genetik Kaynaklarında Ovül-Ovaryum Kültürü Yöntemiyle Haploid Bitki Elde Edilmesi}

\section{Giriş}

Karpuz Citrullus lanatus (Thunb.) Matsum. ve Nakai, kabakgiller (Cucurbitaceae) familyasının bir üyesi olup, dünyanın tropikal ve 1lıman bölgelerinde ekonomik bakımdan önemli bir sebze türüdür (Ellul ve ark., 2007).

Citrullus lanatus botanik olarak 2 alt türe ayrilmakta olup, $C$. lanatus var. lanatus (Thunb.) Matsum. ve Nakai, Citrullus cinsi içerisinde kültürü yapılan, Batı Afrika orijinli türdür. C. lanatus var. citroides (L. H. Bailey) citron ve 'tsamma' cinsi yemeklik, tohum üretimi ve hayvan yemi olarak Doğu ve Güney Afrika'da yaygın biçimde kullanılmaktadır (Jarret ve ark., 1997; Robinson ve Decker-Walters, 1997; Grin, 2012). Bitki genetik kaynakları, doğrudan ya da dolaylı olarak dünyada herkesin geçimini destekler ve gida güvenliğinin biyolojik bir ilkesidir. Gıda ve tarım için bitki genetik kaynakları, geleneksel ve modern çeşitler, yabani bitki türleri ve tohumların çeşitliliğinden oluşmaktadır (FAO, 2018). Bitkilerin kültüre alınması yaklaşı 10.000 yıl önce başlamış, daha sonra sistematik olarak toplanarak bilimsel bir şekilde kullanılmaya başlanmış ve bitkisel üretimin en önemli girdisini oluşturmuştur (Gepts ve ark., 2012). Bitki genetik kaynaklarının korunması, sürdürülebilir kullanımı gıda güvenliği ve tarımsal biyoçeşitlilik için önemli bir konudur ve bitki ıslah çalışmaları için kaynak niteliğindedir (Grausgruber ve ark., 2016). Zengin genetik çeşitlilik, bitki ıslah programları açısından önem kazanmaktadır. Yeni çeşitlerin geliştirilmesinde, özellikle yerel çeşitler kullanılmaktadır. Biyoteknolojik yöntemler arasında, haploid ve katlanmış haploid teknolojisi gametik embriyogenezis yoluyla bitki ıslahına yardımcı, yararlı bir araç olarak bilinmektedir. Haploidler, gametofitik kromozom sayisıyla sporofitik bitkiler olmasına karşın, katlanmış haploidler kendiliğinden ya da kromozom duplikasyonu sonucu uyarılmış haploid bitkilerdir. Haploid Üniversitesi Ziraat Fakültesi Bahçe Bitkileri Bölümü karpuz genetik kaynak koleksiyonunda yer alan - Kar 23, Kar 37, Kar 116 ve Kar 147 olmak üzere toplamda 4 adet genotip kullanılmıştır. Araştırmada araştırmalarının temel amacı, ıslah programlarına uygun evrensel olarak diploid hatlar elde etmektir (Dong ve ark., 2016). Diploid bitkiler, genetik bilgi taşıyan gametlerinde yalnızca bir kromozom grubu taşırlar ve bundan dolayı genetik açıdan homozigotik olarak kabul edilmektedir (Juhász ve Jakše, 2005). Haploid bitkilerden, kolhisin uygulamaları sayesinde dihaplodizasyon adı verilen yöntemle homozigot diploid bitkiler elde edilmektedir (Mishra ve Goswami, 2014). Biyoteknolojik sslah metodları arasında olan in vitro katlanmış haploid tekniği, \% 100 homozigot hatlar ve kisa sürede homozigotiyi yalnızca bir generasyonda istenilen özellikte sağlamaktadır (Arı ve ark., 2016). Haploid bitkiler in vitro kültürde anter ya da izole edilen mikrosporla (androgenezis), ovül (ginogenezis) veya ışınlanmış polenle (partenogenezis) in sitü tozlamayla oluşan partenogenetik embriyoların in vitro'da kurtarlmasiyla elde edilmektedir (Gonzalo ve ark., 2011). Ginogenezis, döllenmemiş ovaryum, ovül veya dişi gametofitlerin kültüre alınması işlemidir (Zhao ve ark., 2014). Birçok türün ıslahında ginogenezis yöntemi başarılıdır, fakat karpuz islahında bu yöntemin etkinliği sinırlı olmuştur (Zou ve ark., 2018). $\mathrm{Bu}$ çalışmada, ülkemizde Cucurbitaceae familyası içerisinde üretimin en fazla yapıldığ 1 karpuzda genetik kaynaklardan yararlanılarak biyoteknolojik yöntemlerden biri olan ovül-ovaryum kültürüyle haploid bitkiler elde etmek amaciyla kullanılan ortam kombinasyonlarının ovül-ovaryum kültürü üzerine etkileri araştırılmıştır.

\section{Materyal ve Yöntem}

$\mathrm{Bu}$ araştırma, Çukurova Üniversitesi Ziraat Fakültesi Bahçe Bitkileri Bölümü Araştırma ve Uygulama seraları ile Çukurova Üniversitesi Biyoteknoloji Araştırma ve Uygulama Merkezi-Doku Kültürü Laboratuvarlarında yürütülmüştür. kullanılan 4 genotipe ait tohumlar 21.02.2018 tarihinde her genotipten 40 'ar fide elde etmek üzere içerisinde 2:1 oranında torf ve perlit karışımı bulunan viyollere ekilmiştir. Fideler 2-3 gerçek yapraklı dönemde iken, 


\section{Karpuz Genetik Kaynaklarında Ovül-Ovaryum Kültürü Yöntemiyle Haploid Bitki Elde Edilmesi}

01.04.2018 tarihinde (100-50) x $50 \mathrm{~cm}$ aralik mesafeler ile plastik seraya her genotipten 40 'ar adet olacak şekilde çift sıralı olarak dikilmiştir. Sulamada damlama sulama sistemi kullanılmış, bitki gelişimi için gübreleme ve ilaçlama işlemleri uygulanmıştır. Bitkiler ipe sardırılarak tek gövdeli olarak yetiştirilmiştir. Çalışmada, MS besi ortamı kullanılmış, $11.36 \mu \mathrm{M} / 1$ ve 22.72 $\mu \mathrm{M} / 1$ 2.4-D (Metwally ve ark., 1998; Rakha ve ark., 2012; Tulukoğlu, 2014), $12.5 \mu \mathrm{M} / 1$ ve $25 \mu \mathrm{M} / 1$ TDZ (Gürsoy ve ark., 2012) ile poliaminlerin (putresin ve spermidin) 500 $\mu \mathrm{M} / 1$ dozu (Kumar ve ark., 2004) ayr1 ayrı ve her ikisi birlikte eklenmiştir. Bütün ortamlarda standart olacak şekilde MS $+8 \mathrm{~g} / 1$ agar $+30 \mathrm{~g} / 1$ sakkaroz ilave edilmiş, ortam pH'sı 5.7'ye ayarlanmıştır. Toplamda 16 adet ortam kombinasyonu hazırlanmıştır (Çizelge 1). Ortamlar otoklav cihazında $121{ }^{\circ} \mathrm{C}^{\prime} \mathrm{de}$, $1.2 \mathrm{~atm}$ basınç altında, $15 \mathrm{dk}$. süreyle sterilize edilmiştir. Otoklavlanma işlemi sonrasında çıkarılan ortamlar, oda sicaklığında soğutularak steril kabin içerisinde $60 \mathrm{~mm}$ 'lik steril petri kutularına yaklaşık $10 \mathrm{ml}$ olacak şekilde dökülmüsştür. Ovül-ovaryum kültürü için iki deneme kurulmuş, birinci denemede dişi çiçekler antezisten 1 gün önce, ikinci denemede ise antezisten 2 gün önce çiçek saplarından kesilerek toplanmış, yüzey sterilizasyonu için laboratuvara getirilmiştir.

Dişi çiçekler çiçek saplarından ayrılmış (Gürsoy ve ark., 2012) ve ilk olarak steril saf suda yıkanmış ardından steril kabine alınarak \% 70'lik etil alkol çözeltisi içerisinde $2 \mathrm{dk}$. tutulduktan sonra 3-4 kez steril saf suda durulama işlemi yapılmıştır (Gürsoy ve ark., 2012; Tulukoğlu, 2014). Daha sonra ovaryumlar 1-2 damla Tween 20 damlatılan $\% 1^{\prime}$ 'lik sodyum hipoklorit solüsyonu içerisine $15 \mathrm{dk}$. boyunca sürekli çalkalanarak bekletilmiştir. Ardından 3-4 kez steril saf su ile durulandıktan sonra yüzey sterilizasyonu tamamlanmıştır. Ovül kültürü için, ovaryumlar pens ve bistüri yardımıyla boyuna kesilerek binoküler stereo mikroskop altında ovüller izole edilmiş ve besi ortamlarına alınmıştır. Her iki denemede, 4 petri kullanılmıs ve her petriye 5 adet ovül yerleştirilmiştir. Birinci deneme için (antezisten 1 gün önce), kültüre alınan ovüller $35^{\circ} \mathrm{C}$ 'de 3 gün (Diao ve ark., 2009; Moqbeli ve ark., 2013; Tantasawat ve ark., 2015) süreyle sıcaklık şoku uygulamasıyla inkübe edilmiştir. Sicaklık şokundan sonra petriler, 25-26 ${ }^{\circ} \mathrm{C}$ sicakliktaki, 3000-4000 lüks 1şık yoğunluğuna sahip 16 saat aydınlık, 8 saat karanlık 1şıklanma sürelerine sahip iklim odalarına alınarak gelişimleri gözlemlenmiştir. İkinci denemede (antezisten 2 gün önce) ovüller sıcaklık şoku uygulaması yapilmadan direkt iklim odalarına transfer edilmiştir.

Ovaryum kültürü için, sterilizasyonu tamamlanmış sslak haldeki ovaryumlar steril filtre kağıdı üzerinde yeteri kadar kurutulduktan sonra steril penset yardımıyla ovaryumun dış yüzeyi hafifçe sıyrılarak uzaklaştırılmıştır. Yüzeyi sıyrılarak alınan ovaryumlar enine ve boyuna dilimlenerek embriyo teşvik amaciyla hazırlanan ortamlara alınmıştır ve her iki denemede, 4 petri kullanılmıs ve her petriye 3 adet ovaryum parçası yerleştirilmiştir.

Birinci denemede (antezisten 1 gün önce), ovaryumlara $35^{\circ} \mathrm{C}^{\prime}$ de 3 gün süreyle sicaklık şoku uygulaması yapılmış, ikinci ovül kültürü (antezisten 2 gün önce) denemesinde, sicaklik ön uygulamas1 yapilmadan ovaryumlar direkt iklim odalarına transfer edilmiştir. Kültüre alınan ovül ve ovaryumlar büyütme odalarında 8 hafta süreyle gelişimleri takip edilmiştir.

Ovül ve ovaryumların üzerinde oluşan kallus ya da embriyo benzeri yapilardan embriyonun gelişmesi amacıyla $13.32 \mu \mathrm{M} / 1$ BAP ve $5.36 \mu \mathrm{M} / 1$ NAA (Song ve ark., 2007) ilave edilmiş MS ortamında alt kültüre alındiktan sonra bu embriyoların çimlendirilmesi için MS ortamına $2.22 \mu \mathrm{M} / 1$ $\mathrm{BAP}, 3 \mathrm{~g}$ sükroz ve $8 \mathrm{~g}$ agar ilave edilmiştir (Abdollahi ve ark., 2015).

Kültür süresi sonucunda şişerek büyüme gösteren ve renk değiştirerek kallus ya da embriyojenik kallus benzeri yapılar meydana getiren ovül sayıs1, kültüre alınan toplam ovül sayısına, kallus oluşturan ovaryum sayısı ise, kültüre alınan toplam ovaryum sayısına oranlanarak yüzdelik olarak değerlendirilmiştir. 


\section{Karpuz Genetik Kaynaklarında Ovül-Ovaryum Kültürü Yöntemiyle Haploid Bitki Elde Edilmesi}

Çizelge 1. Kullanılan besi ortamı kombinasyonları

\begin{tabular}{|c|c|c|c|c|}
\hline \multirow[b]{2}{*}{$\begin{array}{l}\text { Ortam } \\
\text { No }\end{array}$} & \multicolumn{4}{|c|}{$\begin{array}{l}\mathrm{MS}+30 \mathrm{~g} / 1 \text { sakkaroz }+8 \mathrm{~g} / \mathrm{l} \text { agar }+\mathrm{pH} \\
5.7 \text { standart olmak üzere }\end{array}$} \\
\hline & $\begin{array}{l}2,4-\mathrm{D} \\
(\mu \mathrm{M} / \mathrm{l})\end{array}$ & $\begin{array}{l}\mathrm{TDZ} \\
(\mu \mathrm{M} / 1)\end{array}$ & $\begin{array}{l}\text { Putresin } \\
(\mu \mathrm{M} / \mathrm{l})\end{array}$ & $\begin{array}{l}\text { Spermidin } \\
(\mu \mathrm{M} / \mathrm{l})\end{array}$ \\
\hline 1 & 11.36 & 12.5 & - & - \\
\hline 2 & 11.36 & 12.5 & - & 500 \\
\hline 3 & 11.36 & 12.5 & 500 & - \\
\hline 4 & 11.36 & 12.5 & 500 & 500 \\
\hline 5 & 11.36 & 25 & - & - \\
\hline 6 & 11.36 & 25 & - & 500 \\
\hline 7 & 11.36 & 25 & 500 & - \\
\hline 8 & 11.36 & 25 & 500 & 500 \\
\hline 9 & 22.72 & 12.5 & - & - \\
\hline 10 & 22.72 & 12.5 & - & 500 \\
\hline 11 & 22.72 & 12.5 & 500 & - \\
\hline 12 & 22.72 & 12.5 & 500 & 500 \\
\hline 13 & 22.72 & 25 & - & - \\
\hline 14 & 22.72 & 25 & - & 500 \\
\hline 15 & 22.72 & 25 & 500 & - \\
\hline 16 & 22.72 & 25 & 500 & 500 \\
\hline
\end{tabular}

\section{Bulgular ve Tartışma}

Kar 23 genotipi birinci denemeye ait ovüllerde en yüksek ovül gelişimi 14 no'lu ortamda $\% 75$ oranında, en yüksek kallus oluşumu \% 10 oranı ile 4 ve 8 no'lu ortamlarda elde edilmiştir. Kar 23 genotipi ikinci denemeye ait ovüllerde en yüksek ovül gelişimi \% 95 oranı ile 3 ve 10 no'lu ortamlarda gözlenmiştir. Birinci denemeye ait ovaryumlarda en yüksek ovaryum gelişimi \% 77 oranında 4 no'lu ve 15 no'lu ortamlarda görülürken, kallus oluşumunda herhangi bir gelişme olmamıştır. İkinci denemeye ait ovaryumlarda en yüksek ovaryum gelişimi \% 41 oranı ile 12 ve 16 no'lu ortamlarda gözlenmiş, kallus oluşumu ise, \% 16 oranında 15 no'lu ortamda gerçekleşmiştir (Şekil 1.)

Kar 37 genotipi birinci denemeye ait ovüllerde en yüksek ovül gelişimi $\% 100$ oranında $1,2,3$ ve 15 no'lu ortamlarda, kallus oluşumu ise \% 75 oranında 3 no'lu ortamda görülmüştür. Şişen, renk değiştiren ovüllerden embriyojenik kallusun meydana geldiği 6 no'lu ortamda bitkicik formasyonu gözlenmiştir. İkinci denemeye ait ovüllerde en yüksek ovül gelişimi $\% 95$ oranında 3 ve 10 no'lu ortamlarda görülürken, kallus oluşumu \% 5 oranında olup 1, 4 ve 8 no'lu ortamlarda gerçekleşmiştir. Kar 37 genotipi birinci denemeye ait ovaryumlarda en yüksek ovaryum gelişimi \% 88 oranı ile 10 no'lu ortamda gerçekleşmiştir. Kallus oluşumu \% 22 oranında 4 no'lu ortamda görülmüştür. İkinci denemeye ait ovaryumlarda en yüksek ovaryum gelişimi $\% 75$ oranında 3 ve 11 no'lu ortamlarda kaydedilmiştir. Kallus oluşumu \% 25 oranında 4 no'lu ortamda gerçekleşmiştir (Şekil 2.).

Kar 116 genotipi birinci denemeye ait ovüllerde en yüksek ovül gelişimi $\% 66$ oranı ile 3 ve 6 no'lu ortamlarda gözlenirken, kallus oluşumu en yüksek \% 40 oranı ile 11 no'lu ortamda elde edilmiştir. İkinci denemede en yüksek ovül gelişimi \% 95 oranı ile 14 no'lu ortamda gözlenirken, kallus oluşumu en yüksek \% 25 oranında 10 no'lu ortamda kaydedilmiştir. Birinci denemeye ait ovaryumlarda en yüksek ovaryum gelişimi \% 33 ve kallus oluşumu \% 11 oranında görülmüştür. İkinci denemeye ait ovaryumlarda en yüksek ovaryum gelişimi \% 25 oranında 14 no'lu ortamda görülürken, kallus oluşumu $\% 8$ oranı ile 14 no'lu ortamda gerçekleşmiştir (Şekil 3.).

Kar 147 genotipi birinci denemeye ait ovüllerde en yüksek ovül gelişimi \% 100 oranında beş farklı ortamda kaydedilmiş, kallus oluşumu en yüksek \% 75 oranında 8 no'lu ortamda tespit edilmiştir. İkinci denemeye ait ovüllerde en yüksek ovül gelişimi $\% 95$ oranında 3 ve 10 no'lu ortamlarda görülmüştür. Birinci denemeye ait ovaryumlarda en yüksek ovaryum gelişimi \% 100 oranında 13 no'lu ortamda görülürken, kallus oluşumu \% 11 oranında 12 no'lu ortamda gözlenmiştir. 


\section{Karpuz Genetik Kaynaklarında Ovül-Ovaryum Kültürü Yöntemiyle Haploid Bitki Elde Edilmesi}
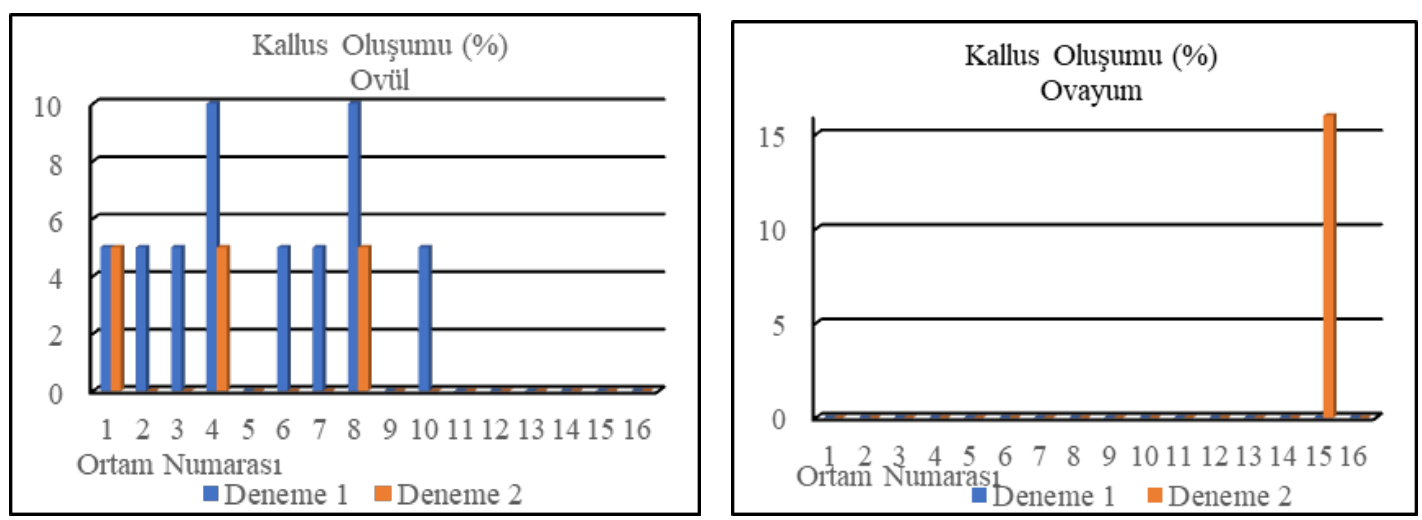

Şekil 1. Kar 23 genotipine ait birinci-ikinci deneme ovül-ovaryum kültürü sonuçları

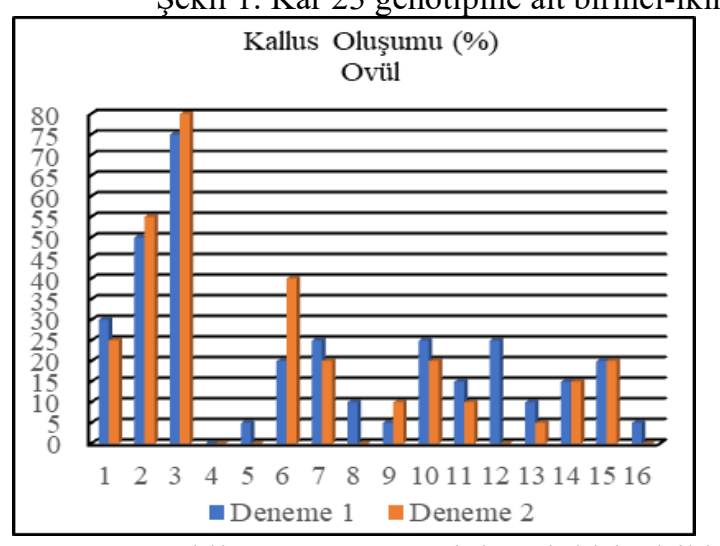

Kallus Oluşumu (\%)

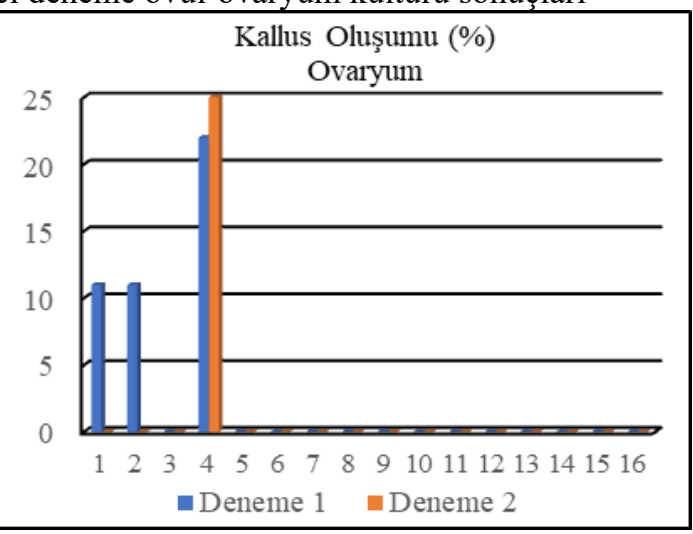

Șekil 2. Kar 37 genotipine ait birinci-ikinci deneme ovül-ovaryum kültürü sonuçları
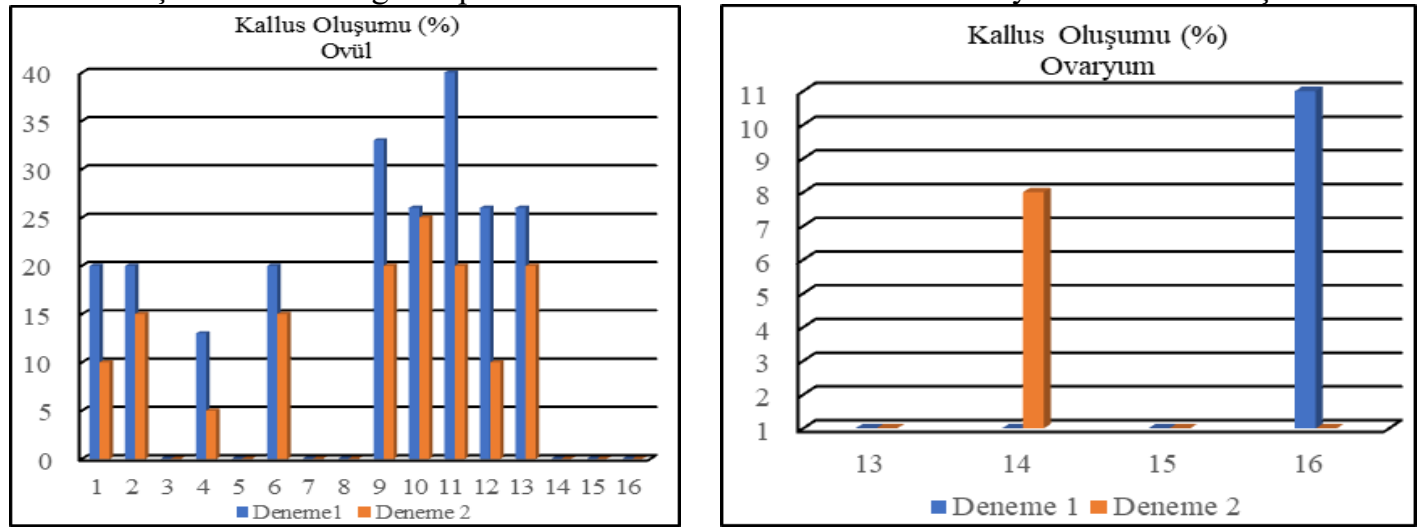

Şekil 3. Kar 116 genotipine ait birinci-ikinci deneme ovül-ovaryum kültürü sonuçları

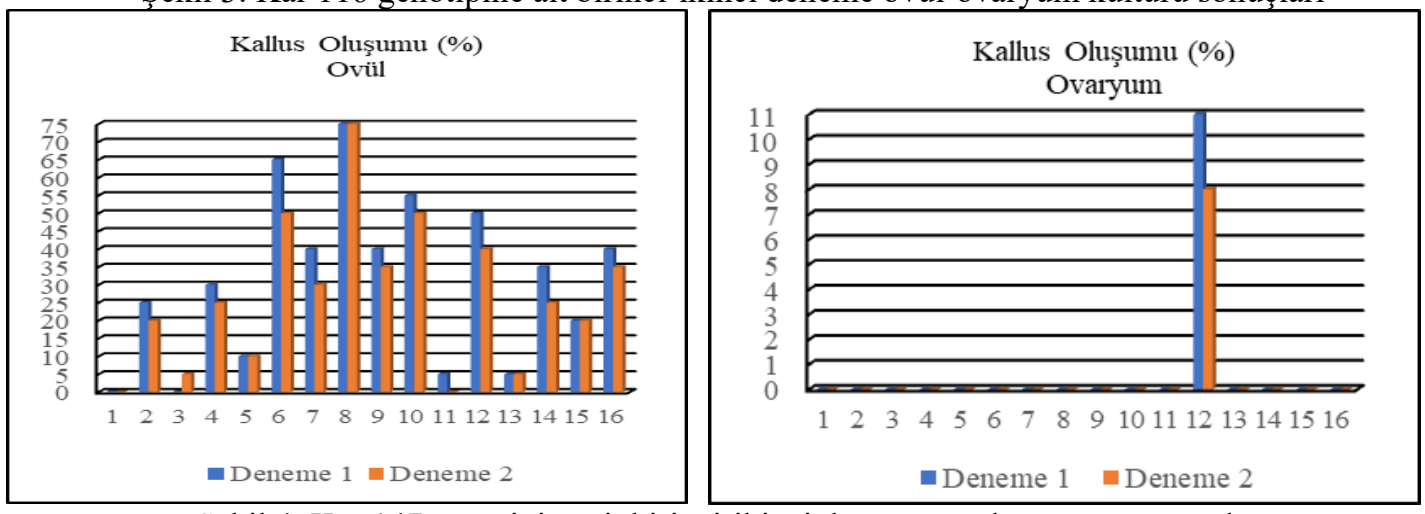

Şekil 4. Kar 147 genotipine ait birinci-ikinci deneme ovül-ovaryum sonuçları 


\section{Karpuz Genetik Kaynaklarında Ovül-Ovaryum Kültürü Yöntemiyle Haploid Bitki Elde Edilmesi}

İkinci denemeye ait ovaryumlarda en yüksek ovaryum gelişimi \% 91 oranında 12 no'lu ortamda görülürken, kallus oluşumu ise $\% 8$ oranı ile yine 12 no'lu ortamda gerçekleşmiş̧ir (Şekil 4.)

Haploid ve double haploidlerin elde edilmesinde ovül-ovaryum kültürünün başarısının; donör bitkinin genotipi, düşük/yüksek sıcaklık ön uygulamaları, dişi gametofitin gelişim dönemi, büyüme düzenleyiciler ya da diğer ortam kompozisyonları ve kültür koşulları gibi birçok faktöre bağlı olduğu yapılan çalışmalarda gösterilmektedir (Dong ve ark., 2016). Gürsoy ve ark., (2012) tarafindan karpuzda antezisten 1 gün sonra aldıkları dişi çiçekleri izole ederek yaptıkları ovül kültüründe kallus oluşumunda en iyi sonucu MS+1 mg/l TDZ, CBM+1 mg/l TDZ, $\mathrm{CBM}+1 \mathrm{mg} / 1 \mathrm{TDZ}+1 \mathrm{mg} / \mathrm{l} \mathrm{SPM}$ içeren ortamlarda almışlardır. Tulukoğlu, (2014) ovüllerin şişip yeşil renk alması sonucunda elde ettiği bitkicik formasyonunun en yüksek olduğu $5 \mathrm{mg} / \mathrm{l}$ 2.4-D + $0.04 \mathrm{mg} / \mathrm{l} \mathrm{TDZ}$ ortamında gerçekleștiğini bildirmiștir. Kullandığımız kombinasyonlardan TDZ'nin her iki dozunun poliaminlerle birlikte olduğu ortamlarda kallus oluşumunu olumlu yönde etkilediği gözlenmiştir. Martínez ve ark., (2000) donör bitki genotipinin döllenmemiş ovül-ovaryum kültüründe şüphesiz belirleyici bir rol oynadığını ve ginogenezisin etkinliği kullanılan çeşide, bitkinin büyüme koşullarına ve donör materyalin kalitesine büyük oranda bağlı olduğunu bildirmişlerdir. Elde edilen veriler doğrultusunda özellikle Kar 23 genotipinde oksin ve sitokininin düşük ve yüksek dozlarına karşılık kallus oluşum oranları çok düşük gerçekleşmiştir.

Kabakgillerde ovül kültürüyle ilgili yapılan çalışmalar incelendiğinde, Metwally ve ark., (1998) kabakta yaptıkları ovül kültüründe ortama eklenen $5 \mathrm{mg} / 1$ 2.4-D'nin diğer konsantrasyonlara göre daha yüksek kallus ve bitkicik oluşturduğu sonucuna varmışlardır. Çalışmamızda ikinci deneme ovül kültüründe 9 no'lu ortamda $5 \mathrm{mg} / 12.4$ D'nin bitkicik formasyonu gerçekleştirdiğini doğrulayabiliriz. Erol, (2018) hıyarda yaptığı ovül kültüründe $0.04 \mathrm{mg} / 1$ TDZ'yi sabit tutarak putresin ve spermidinin ayrı ayrı ve her ikisinin aynı dozlarda birlikte kombinasyonuyla, 2.4-D'nin $5 \mathrm{mg} / 1$ 'l1k dozunun belirlenen ortamlardaki kullanımının haploid embriyo uyartımına etkisini incelemiş ve elde ettiği sonuçlara göre, TDZ'nin tek başına ovül gelişimi üzerine etkisinin oldukça yetersiz kaldığını bildirmiştir. Ovül kültürü denememizde kullandığımız 2.4-D ve TDZ'nin kallus oluşumunu olumlu yönde etkileyerek, poliaminlerle birlikte iş birliği içerisinde olduğunu göstermektedir. Zou ve ark., (2018) karpuzda yaptıkları ovaryum kültürü çalışmalarına göre, elde edilen sonuçlarda donör bitki genotipinin ginogeneziste kilit unsur olduğunu bildirmişlerdir. Kültüre aldıkları ovaryumları $35^{\circ} \mathrm{C}$ 'de 4 gün sicaklık uygulamasının ardından ovaryum parçaları üzerindeki ovüllerin yeşil renge dönüştüğünü, belirli bir süre sonra ovaryumları olgunlaşma ortamına transfer ettiklerini ve sonrasinda embriyo benzeri yapıların göründügünü rapor etmişlerdir. Çalışmamızda sıcaklık ön uygulamasından sonra kültür süresi boyunca ovaryumlar üzerindeki ovüllerde şişme gözlenmiş fakat embriyo ya da embriyo benzeri yapilar oluşmamıştır. Sicaklık uygulaması yapılmayan ikinci denemeye ait sonuçlarda da aynı durumla karşılaşıımıştır. Kabakgillerde yapılan ovaryum kültürü çalışmalarını değerlendirdiğimizde Diao ve ark., (2009) hiyarda embriyogenezisin başarısının yüksek sicaklık uygulamasının embriyo oluşumu üzerine pozitif etkisi olduğunu tespit etmişler, Özsan ve ark., (2017) ise embriyo oluşumu ve bitkicik rejenerasyonunun genotip ve sicaklık şoku uygulaması arasında bir ilişki olabileceğini bildirmişlerdir.

\section{Sonuç}

Yapılan çalışmada ovül-ovaryum kültüründe elde edilen sonuçlara göre genotip bazında farklı oranlarda ovül/ovaryum gelişimleri ve kallus oluşum yüzdeleri elde edilmiştir. Poliaminlerin ayr1 ayrı kullanıldığ ortamlarda embriyo oluşumu ile birlikte bitkicik formasyonu gözlenmiş ve poliaminlerin embriyogenezis üzerinde etkili olduğu düşünülmüştür. Embriyo oluşumu ve 


\section{Karpuz Genetik Kaynaklarında Ovül-Ovaryum Kültürü Yöntemiyle Haploid Bitki Elde Edilmesi}

bitki gelişimi Kar 37 ve Kar 147 genotiplerinde, $2.5 \mathrm{mg} / 12.4-\mathrm{D}+1 \mathrm{mg} / 1 \mathrm{TDZ}$ $+500 \mu \mathrm{M}$ SPD, $2.5 \mathrm{mg} / 1$ 2.4-D + $1 \mathrm{mg} / 1 \mathrm{TDZ}$ $+500 \mu \mathrm{M}$ PUT ve $5 \mathrm{mg} / 1$ 2.4-D + $0.5 \mathrm{mg} / \mathrm{l}$ TDZ bulunan ortamlarda gözlendiği saptanmış ancak bunlardan tam bir bitki elde edilememiştir. Birçok türün 1slahında ginogenezis yöntemi başarılıdır, fakat karpuz 1slahında bu yöntem sinırlı olmaktadır. Ginogenezisin başarısının karpuzda düşük olmasına yönelik olarak, bu konuda uygun protokol geliştirip haploid bitki elde edilmesinde daha iyi bir alternatif yöntem haline getirmek amacıyla yeni çalışmaların yapılması gerektiği düşünülmektedir.

\section{Teşekkür}

*Bu çalışma Çağlar YILDIZ'ın Yüksek Lisans tezinden üretilmiştir. Araştırma, Çukurova Üniversitesi Bilimsel Araştırma Projeleri Birimi tarafından desteklemiştir. (Proje No: FYL-2018-10623).

\section{Kaynaklar}

Abdollahi, M.R., Darbandi, M., Hamidvand, Y., Majdi, M. (2015). The Influence Of Phytohormones, Wheat Ovary CoCulture, And Temperature Stress On Anther Culture Response Of Watermelon (Citrullus lanatus L.). Botanical Society Of Sao Paulo, Braz. J. Bot. 38 (3):447-456.

Arı, E., Bedir, H., Yıldırım, S., Yıldırım, T. (2016) Androgenic Responses Of 64 Ornamental Pepper (Capsicum Annuum L.) Genotypes To Shed-Microspore Culture In The Autumn Season. Turkish Journal Of Biology. 40:706-717.

Diao, W.P., Jia, Y.Y., Song, H., Zhang, X.Q., Lou, Q.F., Chen, J.F. (2009) Efficient Embryo Induction in Cucumber Ovary Culture and Homozygous Identification of The Regenetants Using Ssr Markers. Scientia Horticulturae, 119 (3), 246-251.

Dong, Y.Q., Zhao, W.X., Li, X.H., Liu, X.C., Gao, N.N., Huang, J.H., Wang, W.Y., $\mathrm{Xu}, \quad$ X.L., Tang, Z.H. (2016) Androgenesis, gynogenesis, and parthenogenesis haploids in cucurbit species. Plant Cell Rep, 35:1991-2019.

Ellul, P.L.C., Naval, M.M., Nogueral, F.J., Sanchez, S., Atare 'S, A., Moreno, V., Corella, P., Dirks, R. (2007) Watermelon
Biotechnology. Agriculture And Forestry, Transgenic Crops, Pp. 129165.

Erol, M. H. (2018) Hiyarlarda Ovül-Ovaryum Kültürleri ve Işınlanmış Polen Tekniği ile Spermidin ve Putresin Uygulamalarının Haploid Embriyo Uyartımına Etkileri. (Yüksek Lisans Tezi), Çukurova Üniversitesi Fen Bilimleri Enstitüsü, Adana, 99 s.

Grausgruber, H., Hochhauser, F., Naderer, L. (2016) Utilisation Of Plant Genetic Resources For Food And Feed: Case Studies Of Spelt Wheat And Barley. In: Daniela B. (Eds.) International Scientific Conference On Sustainable Utilisation Of Plant Genetic Resources For Agriculture And Food. 18-20. Piešt'any, Slovak Republic.

Gepts, P., Bettinger, R., Brush, S. (2012) Biodiversity in agriculture: domestication, evolution and sustainability. In: Bettinger R. (Eds.) Early steps in agricultural domestication. Cambridge University Press, Cambridge, pp 19-20.

Gonzalo, M.J., Claveria, E., Monforte, A.J., Dolcet-Sanjuan, R. (2011) Parthenogenic haploids in melon: generation and molecular characterization of a doubled haploid line population. J. Am. Soc. Hort. Sci., 136(2):145-154.

Grin, (2012) Usda, Ars, National Genetic Resources Program. Germplasm Resources Information Network (GRIN). National Germplasm Resources Laboratory, Beltsville, Maryland. http://www.ars-grin.gov/cgi-

bin/npgs/html/tax_ search.pl/ Erişim Tarihi 14.07.2012.

Gürsoy, I. Solmaz, I., Deliboran, S., Sarı, N. (2012) In vitro Ovule and Ovarium Culture in Watermelon. In Cucurbitaceae 2012. Proceedings of the $X^{\text {th }}$ EUCARPIA Meeting on Genetics and Breeding of Cucurbitaceae, Antalya, Turkey, 15-18 October, 2012, 799-804.

Gürsöz (Sar1), N. (1990) Kavun (Cucumis melo var. inodorus ve reticulatus) ve Karpuzda (Citrullus lanatus (Thunb.) Mansf) Işınlanmış Polenle In Situ Partenogenetik Embriyolardan In Vitro Kültürü İle Haploid Bitki Eldesi. Çukurova Üniversitesi Fen Bilimleri 


\section{Karpuz Genetik Kaynaklarında Ovül-Ovaryum Kültürü Yöntemiyle Haploid Bitki Elde Edilmesi}

Enstitüsü (Yüksek Lisans Tezi), Adana, $60 \mathrm{~S}$.

Jarret, R.L., Merrick, L.C., Holms, T., Evans, J., Aradhya, M.K. (1997) Simple sequence repeats in watermelon (Citrullus lanatus (Thunb.) Matsum. \& Nakai). Genome 40: 433-441.

Juhász, A.G., Jakše, M. (2005) Haploids in the improvement of miscellaneous crop species (Cucurbitaceae, Liliaceae, Asparagaceae, Chenopodiaceae, Araceae and Umbelliferae). Haploids in Crop Improvement II, 259-276.

Fao, (2018) Faostat Statistic Database. http://www.fao.org/ Erişim Tarihi: 24.11.2018.

Kumar, H.G.A., Ravishankar, B.V., Murthy, H.N. (2004) The Influence of Polyamines On Androgenesis of Cucumis Sativus L. Europ. J. Hort. Sci., 69 (5): 201-205.

Martinez, L.E., Aguero, C.B., Lopez, M.E., Galmarini, C.R. (2000) Improvement of In Vitro Gynogenesis Induction in Onion (Allium cepa L.) Using Polyamines. Plant Sci., 156: 221-226.

Metwally, E.I., Moustafa, S.A., El-Sawy, B.I., Haroun, S.A., Shalaby, T.A. (1998) Production Of Haploid Plants From In Vitro Culture Of Unpollinated Ovules of Cucurbita pepo. Plant Cell, Tissue And Organ Culture, 52 (3), 117-121.

Mishra, V. K., Goswami, R. (2014) Haploid Production in Higher Plant. Int. J. Chem. Biol. Sci, 1, 26-45.

Moqbeli, E., Peyvast, G., Hamidoghli, Y., Olfati, J. (2013) In Vitro Cucumber Haploid Line Generation In Several New Cultivars. As. Pac. J. Mol. Biol. Biotechnol., 21 (1), 18-25.

Özsan, T., Gözen, V., Onus A.N. (2017) Cucumber Gynogenesis: Effects of 8 Different Media on Embryo and Plant Formation. International Journal of
Agriculture Innovations and Research 6 (2), ISSN (Online) 2319-1473.

Rakha, M.T., Metwally, E.I., Moustafa, S.A., Etman, A.A., Dewir, Y.H. (2012) Evaluation of Regenerated Strains From Six Cucurbita Interspecific Hybrids Obtained through Anther and Ovule in Vitro Cultures. Australian Journal of Crop Science, 6 (1), 23-30.

Robinson, R.W., Decker-Walters, D.S. (1997) Cucurbits. $\mathrm{Cab}$ International, Wallingford, UK, P. 226.

Song, H., Lou, Q. F., Luo, X. D., Wolukau, J. N., Diao, W. P., Qian, C. T., Chen, J. F. (2007) Regeneration of Doubled Haploid Plants By Androgenesis of Cucumber (Cucumis sativus L.). Plant Cell, Tissue and Organ Culture, 90 (3): 245-254.

Tantasawat, P. A., Sorntip, A., Poolsawat, O., Chaowiset, W., Pornbungkerd, P. (2015) Evaluation of Factors Affecting EmbryoLike Structure and Callus Formation in Unpollinated Ovary Culture of Cucumber (Cucumis sativus). Intl. J. Agr. Biol., 17: 613-618.

Tulukoğlu, K.S. (2014) Karpuzlarda Anter ve Ovül Kültüründe Soğuk Uygulamas1, Thidiazuron (Tdz) ve 2,4-D Uygulamalarının Haploid Embriyo Uyartımına Etkileri. Çukurova Üniversitesi Fen Bilimleri Enstitüsü Bahçe Bitkileri Anabilim Dalı. (Yüksek Lisans Tezi), $78 \mathrm{~S}$.

Zhao, H.,, Wang, X.X., D, Y.C., Zhu, D.W., Guo, Y.M., Gao, J.C., Li, F., John, C.S. (2014) Haploid Induction Via in Vitro Gynogenesis in Tomato (Solanum lycopersicum L.) Journal of Integrative Agriculture, 13 (10), 2122-2131.

Zou, T., Su, H.N., Wu, Q., Sun, X.W. (2018) Haploid Induction Via Unfertilized Ovary Culture in Watermelon. Plant Cell, Tissue and Organ Culture, 135: 179-18. 